\title{
TRADISI MABBACA-BACA PABBILANG PENNI Studi pada Masyarakat Suku Bugis Di Kecamatan Keritang Kabupaten Indragiri Hilir
}

\author{
Nur Kamalia \\ Jurusan Studi Agama-Agama, Fakultas Ushuluddin, UIN SUSKA Riau \\ Email:nur.kamalia@uin-suska.ac.id
}

\begin{abstract}
Abstrak
Tradisi mabbaca-baca pabbilang penni merupakan tradisi membaca doa dalam peringatan arwah (orang yang sudah meninggal) yang dipimpin oleh seorang pabbaca (pendoa). Tulisan ini, merupakan hasil penelitian (field research) dengan menggunakan metode kualitatif. Data diperoleh melalui observasi, wawancara, dan dokumentasi. Analisis data yang digunakan adalab deskriptif analitik. Hasil penelitian menunjukkan babwa: mabbaca-baca pabbilang penni merupakan suatu usaha untuk. memohon doa keselamatan dan mendoakan orang yang telah meninggal. Dupa atau kemenyan, kuekue dan lauk pauk adalah simbol yang digunakan dalam tradisi mabbaca-baca pabbilang penni yang memiliki makna tersendiri. Hal ini didasarkan pada karakteristik dari simbol baik dari rasa maupun bentuknya. Adapun faktor yang menyebabkan masyarakat melaksanakan tradisi mabbaca-baca pabbilang penni, yaitu: faktor adat, faktor sosial dan faktor keyakinan yang didasrkan pada pengalaman masyarakat. Sedangkan nilai-nilai yang terkandung dalam tradisi mabbaca-baca pabbilang penni yaitu nilai religius (agama), nilai sosial dan nilai moral..
\end{abstract}

Kata Kunci: tradisi, mabbaca-baca pabbilang penni, arwah

Abstract:

The mabbaca-baca pabbilang penni tradition is a tradition of reading prayers in commemoration of spirits (dead people) led by a pabbaca (prayer). This paper is the result of research (field research) using qualitative methods. Data obtained through observation, interviens, and documentation. The data analysis used is descriptive analytic. The results showed that: mabbaca-baca pabbilang penni is an attempt to pray for safety and pray for the dead. Incense or incense, pastries and side dishes are symbols used in the mabbaca-baca pabbilang penni tradition which have their own meaning. It is based on the characteristics of both taste and form. The factors that cause people to carry out the mabbaca-baca pabbilang penni tradition, namely: customary factors, social factors and belief factors based on community experience. While the values contained in the mabbaca-baca pabbilang penni tradition are religious values, social values and moral values.

Keywords: tradition, mabbaca-baca pabbilang penni, soul

\section{PENDAHULUAN}

Negara Indonesia merupakan salah satu negara yang memiliki keanekaragaman baik itu berupa budaya, agama, suku, ras, tradisi, dan adat istiadatnya serta bahasa. Maka dari itulah masyarakat Indonesia memiliki adat istiadat dan tradisi yang berbeda-beda pula antara suatu daerah dengan daerah lainya. Setiap daerah yang ada di Indonesia memiliki kebudayaan dengan keunikan tersendiri yang masih dipertahankan secara turun temurun dan terus berkembang dari masa ke masa.
Tidak ada manusia yang bisa hidup di luar ruang lingkup kebudayaan. Kebudayaan yang memberikan nilai dan makna pada hidup manusia. Hakikat kebudayaan sangat penting untuk dipahami, karena seluruh manusia dan masyarakat berdiri di atas landasan kebudayaan. Nilai-nilai kebudayaan yang berlaku pada masyarakat Indonesia sangat beraneka ragam. Hal ini dikarenakan masyarakat Indonesia merupakan bangsa yang majemuk. Kemajemukan dapat dilihat pada setiap daerah tertentu. Setiap daerah tentunya memiliki suatu kebudayaan, di mana kebudayaan 
tersebut memiliki sejarah yang berbeda-beda antara satu daerah dan daerah yang lainya. Hal ini dapat dilihat bahwa setiap daerah memiliki suatu budaya dengan ciri khasnya tersendiri yang berbeda berbeda antara satu daerah dan daerah yang lainya. Kemajemukan yang terdapat di berbagai daerah menjadikan mereka saling mengenal satu sama lain, baik itu antar suku maupun bangsa. ${ }^{1}$

Sebagaimana firman Allah yang terdapat dalam surah al-Hujurat: Artinya: Hai manusia, sesunggubnya Kami menciptakan kamu dari seorang lakilaki dan seorang perempuan dan menjadikan kamu berbangsa-bangsa dan bersuku-suku supaya kamu saling kenal-mengenal. Sesunggubnya orang yang paling mulia diantara kamu disisi Allab ialah orang yang paling taqwa diantara kamu. Sesunggubnya Allah Maha Mengetahui lagi Maha Mengenal [QS. al-Hujurat:13] ${ }^{2}$

Setiap suku di Indonesia memiliki budaya yang berbeda-beda seperti halnya dalam pelaksanaan upacara maupun ritual. Baik itu ritual maupun upacara selamatan, pernikahan, akikah dan kematian. Setiap ritual maupun upacara pada setiap suku memiliki makna tersendiri bagi masyarakat selain itu, terdapat persamaan dan perbedaan yang sering ditemukan dalam ritual maupun upacara tradisi pada setiap suku. Seperti halnya ritual kematian yang ada di beberapa daerah di Indonesia.

Ritual kematian merupakan salah satu bentuk ritual atau upacara untuk memperingati dan mengenang serta menghormati orang yang sudah meninggal. Adapun bentuk upacara maupun ritual kematian dapat dilihat dalam "tradisi bilangan pada suku Melayu di Kuansing dan tradisi kenduri arwah pada suku Melayu Pujud di Rokan Hilir" serta tradisi mabbaca-baca pabbilang penni pada masyarakat suku Bugis. Setiap tradisi memiliki nilai-nilai dan makna tersendiri pada setiap suku.

Tradisi mabbaca-baca pabbilang penni yang dilakukan oleh masyarakat suku Bugis di Kelurahan Kota Baru Reteh Kecamatan Keritang Kabupaten Indragiri Hilir merupakan suatu tradisi yang telah dilakukan dari generasi ke generasi. Tradisi mabbaca-baca pabbilang penni yang dilakukan

${ }^{1}$ Rafael Raga Maran, Manusia dan Kebudayaan Dalam Perspektif Ilmu Budaya Dasar, Cet. I (Jakarta: PT. Rineka Cipta,2000), hlm. 15. oleh masyarakat suku Bugis ini merupakan suatu tradisi memohon doa kepada Allah, baik itu doa untuk keselamatan, doa untuk menghindari bencana, doa untuk orang yang telah meninggal dan lain sebagainya.

Tradisi mabbaca-baca pabbilang penni merupakan salah satu bentuk tradisi untuk mendoakan orang yang telah meninggal di mana usia kematiannya telah sampai pada hari ketiga, hari ketujuh, hari kesembilan, hari keempat puluh dan hari keseratus. Tradisi mabbaca-baca pabbilang penni merupakan salah satu tradisi yang diyakini oleh masyarakat suku Bugis di Kelurahan Kota Baru Reteh Kecamatan Keritang Kabupaten Indragiri Hilir yang sangat penting dan harus dilaksanakan.

Pelaksanaan tradisi mabbaca-baca pabbilang penni yang ada pada masyarakat suku Bugis tidak begitu rumit. Tuan rumah hanya perlu memanggil seorang pabbaca dan membuat beberapa jenis makanan khas suku Bugis yang memiliki makna tersendiri. Seorang pabbaca hanya dapat dilakukan sebagian orang saja atau hanya orang-orang tertentu saja yang bisa menjadi pabbaca, seperti seorang imam, tokoh agama dan orang yang memang dianggap sebagai guru di kampung tersebut.

\section{Proses Pelaksanaan Tradisi Mabbaca-Baca}

Salah satu tradisi masyarakat yang mengakar di Indonesia, terutama di kalangan masyarakat suku Bugis yaitu tradisi mabbaca-baca pabbilang penni, di mana perilaku ini dilakukan oleh masyarakat secara berulang-ulang sehingga kemudian menjadi sebuah kebiasaan atau yang bisa disebut sebagai adat kebiasaan. Hubungan antara agama resmi dengan kepercayaan dalam masyarakat suku Bugis di Kelurahan Kota Baru Reteh dapat dilihat dalam berbagai upacara yang dilakukan oleh masyarakat, salah satunya yaitu: tradisi mabbaca-baca pabbilang penni atau perhitungan hari arwah merupakan salah satu rangkaian tradisi dan ritual nenek moyang yang terdapat dalam tradisi peringatan kematian masyarakat suku Bugis. Tradisi mabbaca-baca pabbilang penni merupakan salah satu tradisi dalam ritual kematian masyarakat suku Bugis yang

2 Ayat al-Qur'an Dengan Terjemahan Dalam Skripsi ini di Kutip Dari Al-Qur'an Word Versi 2010 


\section{NUSANTARA; Journal for Southeast Asian Islamic Studies}

Vol. 16, No. 2, Desember 2020

dilaksanakan sebelum pelaksanaan tradisi mattampung.

Tradisi mabbaca-baca pabbilang penni merupan suatu pembacaan doa untuk perhitungan hari pada salah satu anggota keluarga telah meninggal dunia. Mabbaca-baca Pabbilang Penni dilaksanakan apabila telah memasuki penghitungan hari yang telah ditetapkan. Mabbaca-baca Pabbilang Penni atau perhitungan hari dilaksankan pada hari ke 3, hari ke 7, hari ke 9, hari ke 40 dan hari ke 100 yang di mana masyarakat suku Bugis menyebutnya hal ini dengan nanre tellu (makan ketiga), nanre pitu (makan ketujuh), nanre asera (makan kesembilan), nanre petappulo (makan keempat puluh) dan nanre seratu (makan keseratus).

Mabbaca-baca Pabbilang Penni dapat dilakukan dengan menggabungkan beberapa hari peringatan menjadi satu, namun penggabungan peringatan hari kematian tersebut tidak dapat disatukan semua menjadi satu, akan tetapi penggabungan peringatan hari bisa dilakukan pada hari ke 40 yang kemudian digabungkan pada peringatan hari ke $100 .^{3}$

Adapun proses pelaksanaan tradisi mabbacabaca Pabbilang Penni yang harus dilakukan, yaitu sebagai berikut: Pertama. Penentuan hari. Penentuan hari dalam tradisi mabbaca-baca pabbilang penni tidak ditentukan berdasarkan hari senin, selasa dan lain sebagainya. Penentuan hari dalam mabbaca-baca pabbilang penni ini merupakan penghitungan hari kematian, yang di mana penghitungan hari kematian bertepatan pada hari ke 3, hari ke 7, hari ke 9, hari ke 40 dan hari ke 100 . Adapun pemilihan hari pada tradisi mabbaca-baca pabbilang penni tidak diketahui secara pasti alasan maupun maknanya. Namun pabbilang penni (perhitungan hari arwah) ini dilaksanakan atas dasar ajaran dari nenek moyang atau orang terdahulu.

Kedua, Tahap Persiapan. Tuan rumah menyiapkan bahan dan makanan untuk pabbilang penni serta nanre esso. Tuan rumah dibantu oleh keluarga terdekat dan para tetangga dalam proses pembuatan makanan yang diperlukan dalam mabbaca-baca Pabbilang Penni. Pada tahap persiapan ini dapat dilihat bahwasanya terdapat kemudahan bagi masyarakat untuk menjalin kekerabatan dengan cara saling membantu dan bersilaturahim antar sesama masyarakat. Sehingga dengan ini akan melahirkan dan membangun nilai sosial yaitu berupa rasa solidaritas yang dapat dijadikan sarana untuk mempererat dan memperkokoh tali silaturahim dan memperkokoh persatuan dalam masyarakat.

Adapun makanan khas yang harus disediakan dalam proses mabbaca-baca Pabbilang Penni, yaitu sebagai berikut:

1. Makanan Pada Tradisi Mabbaca-Baca Pabbilang Penni;

Terdapat perbedaan dalam persiapan makanan zaman dahulu dengan zaman sekarang. Hal ini dapat dilihat dalam penyajian makanan, di mana pada saat ini tidak terdapat makanan khusus yang diwajibkan dalam tradisi mabbaca-baca pabbilang penni meskipun masih terdapat beberapa masyarakat yang menyediakan makanan-makanan zaman dahulu yang merupakan makanan khas yang memiliki makna tersendiri dalam tradisi mabbaca-baca pabbilang penni.

Adapun beberapa makanan yang disajikan pada pelaksanaan tardisi mabbaca-baca pabbilang penni yaitu beberapa kue dan lauk pauk. Adapun kue-kue untuk mabbaca-baca pabbilang penni, yaitu: beppa cucuru' maddingking, beppa buah seppang, beppa tencaji atau baje silele dan beppa leyya. Lauk pauk untuk pabbilang penni, yaitu: Peria (Pare), Bale Gulama atau Bale Kemme (ikan gulama) dan Manu Ceddi (Ayam Satu Ekor).

Lauk pauk yang disediakan untuk mabbacabaca pabbilang penni terdiri dari dua talam (dua kappera'), di mana 1 talamnya terdiri dari 12 piring kecil (pinceng beccu) yang berisi lauk pauk seperti pare, ikan gulama dan ayam 1 ekor, di mana ayam tersebut di potong menjadi beberapa bagian dan kemudian di masak. Adapun talam yang ke 2 terdiri dari 12 piring kecil yang berisi beberapa macam kue, seperti beppa cucuru' maddingking, beppa buah seppang, beppa tencaji atau baje silele dan beppa leyya.

\footnotetext{
${ }^{3}$ Syaharudin (Pabbaca), Wawancara, 16 April 2021
} 
Namun pada zaman sekarang makanan khas yang biasa disediakan oleh orang terdahulu pada tradisi mabbaca-baca pabbilang penni sudah jarang disediakan oleh masyarakat pada saat ini, hal ini dikarenakan kurangnya keahlian masyarakat setempat dalam membuat makanan-makanan khas tersebut. Sehingga pada zaman sekarang makanan-makan yang disediakan untuk tradisi mabbaca-baca pabbilang penni sudah beraneka ragam, ada yang membuat kue bolu, kue onde-onde dan lain sebagainya.

Makanan untuk Nanre Esso merupakan pemberian makanan harian untuk anggota keluarga yang telah meninggal dunia. Adapun makanan yang disiapkan oleh tuan rumah untuk nanre esso atau pemberian makanan harian disesuaikan dengan kemampuan dari tuan rumah itu sendiri dan tidak ada paksaan maupun syarat tertentu dalam menyediakan hidangan nanre esso (makan harian). Namun, biasanya tuan rumah menyesuaikan dengan makanan kesukaan almarhum ketika masih hidup

2. Media pada tradisi mabbaca-baca pabbilang penni Adapun media yang wajib disiapkan oleh tuan rumah untuk tradisi mabbaca-baca pabbilang penni yaitu pesse' pelleng (dupa) atau kemenyan dan colo' (pancis). Apabila tuan rumah tidak memiliki pesse' pelleng (dupa) maka tuan rumah bisa mengganti pesse' pelleng (dupa) dengan kemenyan. Pesse' pelleng (dupa) yang disediakan biasanya di tancapkan pada gelas atau wadah yang berisi beras. Namun, apabila tuan rumah tidak memiliki pesse' pelleng (dupa) maka tuan rumah harus menyediakan kemenyan bersamaan dengan dapo beccu (anglo kecil) dan colo' (pancis).

Ketiga, Tahap pelaksanaan. Tradisi mabbaca-baca pabbilang penni dilakukan oleh masyarakat sebagai bentuk penghormatan dan peringatan hari arwah pada masyarakat suku Bugis. Tradisi mabbaca-baca pabbilang penni di lakukan oleh tuan rumah apabila terdapat anggota keluarga yang baru meninggal dunia. Adapun tahap pelaksanaan Tradisi mabbaca-baca pabbilang penni dilaksanakan apabila telah mecapai hari yang telah ditentukan misalnya nanre tellu (makan ketiga), nante pitu (makan ketujuh), nanre asera (makan kesembilan), nanre petappulo (makan keempat puluh) dan nanre seratu (makan keseratus). Pelaksanaan tradisi mabbaca-baca pabbilang penni ini dilakukan pada saat ba'da zuhur dan apabila semua makanan telah tersedia dan disusun, maka salah satu tuan rumah pergi memanggil seorang pabbaca. Apabila pabbaca telah sampai maka anggota keluarga berkumpul dan kemudian pabbaca menghidupkan dupa atau kemenyan serta langsung membacakan doa pabbilang penni dan kemudian dilanjutkan dengan pembacaan doa untuk nanre esso.

Terdapat beberapa surah dan doa yang dibaca oleh seorang pabbaca dalam pelaksanaan mabbacabaca pabbilang penni, diantaranya: Surah atau doa yang dibaca yaitu dimulai dari membacakan surah al-Fatihah dilanjutkan dengan Surah al-Ikhlas sebanyak tiga kali, surah al-Falaq, surah an-Nas, surah al-Fatihah, surah al-Baqarah Ayat 1-5, Ayat kursi, dan doa selamat. Namun, seorang pabbaca juga dapat menambahkan beberapa surah maupun doa-doa yang lain. Adapun doa yang dibacakan untuk nanre esso/ makan harian itu tidak berbeda jauh dengan doa yang dibacakan untuk mabbacabaca pabbilang penni. Doa untuk nanre esso (makan harian) hanya ditambahkan dengan niat untuk pemberian makan yang bertepatan pada harinya dan kemudian ditambahkan dengan doa ibu bapak, doa tahlil dan terakhir surah al-Fatihah.

Setelah pabbaca selesai membacakan doa pabbilang penni dan nanre esso maka anggota keluarga dan para tetangga makan bersama. Adapun sisa makanan yang telah dihidangkan dalam pelaksanaan tradisi mabbaca-baca pabbilang penni maka makanan tersebut tidak boleh lagi dibawa ke dapur dan harus tetap diletakkan di ruang tamu, hal ini dilakukan untuk menghindari rasa panas dalam keluarga si mayit serta untuk menghindari terjadinya kematian secara beruntun dalam keluarga tersebut. Setelah selesai para anggota keluarga dan masyarakat makan bersama, biasanya para tetangga saling membantu untuk mencuci piring, adapun pelaksanaan pencucian piring harus dikerjakan diluar rumah, piring-piring kotor tersebut tidak boleh dicuci di dalam rumah. Hal ini dikarenakan untuk menghindari agar arwah si mayit tidak masuk kedalam rumah.

\author{
Makna Simbolik Tradisi Mabbaca-Baca Pada \\ Masyarakat Suku Bugis
}


Penjelasan dari beberapa masyarakat maka dapat kita ketahui makna simbolik yang ada pada masyarakat suku Bugis di Kelurahan Kota Baru Reteh Kecematan Keritang Kabupaten Indragiri Hilir. Adapun makna simbolik tersebut, yaitu sebagai berikut:

1. Pesse' Pelleng (Dupa) atau kemenyan memiliki makna sebagai sarana penyampaian dan baunya bermakna sebagai pengharum dalam kehidupan bagi orang-orang yang melakukan tradisi mabbaca-baca.

2. Colo' (Pancis) tidak memiliki makna khusu dalam tradisi ini kerana pancis merupakan sarana yang digunakan oleh pabbaca untuk menghidupkan dupa atau kemenyan.

3. Peria (Pare) merupakan suatu simbolik yang mewakilkan atau melambangkan rasa kepahitan yang dialami oleh anggota keluarga atas meninggalnya salah satu anggota keluarga.

4. Bale Gulama atau Bale Kemme (ikan gulama) merupakan suatu simbol dalam tradisi mabbacabaca pabbilang penni yang mempunyai makna seperti rasa yang terdapat pada ikan gulama, yang dimana rasa yang ada pada ikan gulama merupakan perwakilan dari perasaan anggota keluarga yang di tinggalkan akan merasakan kehampaan dan hambar atas meninggalnya salah satu anggota keluarganya

5. Manu Ceddi (Ayam Satu Ekor) ini tidak diketahui secara pasti maknanya karena masyarakat meyakini bahwa dalam proses mabbaca-baca pabbilang penni ayam harus disiapkan oleh tuan rumah dan hal ini dilakukan oleh masyarakat karena mereka hanya mengikuti apa yang dikerjakan oleh orang terdahulu.

6. Beppa Cucuru' Maddingking bermakna sebagai bentuk permohonan doa kepada Allah.

7. Beppa Buah Seppang memiliki makna yang melambangkan sebuah harapan yang dapat membawa keberkahan dari Allah SW'T serta untuk mendapatkan keselamatan dari Allah SWT.

8. Beppa Tencaji atau Baje Silele merupakan sebuah bentuk yang melambangkan bahwa pihak keluarga belum siap atau tidak siap untuk kehilangan anggota keluarganya.
9. Beppa Leyya ini tidak diketahui secara pasti maknaya. Penyajian Beppa Leyya dan 1 ekor ayam dalam tradisi mabbaca-baca pabbilang penni ini dilakukan sebagai bentuk pelestarian budaya nenek moyang.

Faktor yang Menyebabkan Masyarakat Suku Bugis Melaksanakan Tradisi Mabbaca-Baca Pabbilang Penni.

Faktor yang menyebabkan masyarakat suku Bugis di Kelurahan Kota Baru Reteh Kecamatan Keritang Kabupaten Indragiri Hilir tetap melaksanakan tradisi mabbaca-baca pabbilang penni bergantung pada persepsi dari masyarakat itu sendiri. Terdapat beberapa faktor yang menyebabkan masyarakat suku Bugis di Kelurahan Kota Baru Reteh Kecamatan Keritang Kabupaten Indragiri Hilir tetap melaksanakan tradisi ma bbacabaca pabbilang penni, yaitu:

Pertama, Faktor Adat. Tradisi mabbaca-baca pabbilang penni merupakan suatu tradisi yang telah dilaksanakan secara turun temurun oleh masyarakat Kelurahan Kota Baru Reteh. Tradisi ini dilaksanakan oleh masyarakat Kelurahan Kota Baru Reteh sebagai bentuk untuk melestarikan adat dan budaya suku Bugis, hal ini merupakan cerminan dari wujud tanggung jawab terhadap tradisi serta untuk mewujudkan kebersamaan antar masyarakat. Berikut penuturan dari beberapa masyarakat. Tradisi mabbaca-baca pabbilang penni harus tetap dilaksanakan, hal ini dikarenakan mabbaca-baca pabbilang penni merupakan suatu tradisi yang telah diwariskan oleh nenek moyang atau orang terdahulu. Mabbaca-baca pabbilang penni harus tetap dilaksanakan meskipun seseorang telah merantau.

Kedua, Faktor Sosial. Manusia merupakan makhluk sosial (social buman being) yang dalam kehidupannya tidak bisa hidup sendiri sehingga membentuk suatu kesatuan hidup yang disebut dengan masyarakat. Menurut Koentjaraningrat yang dikutip oleh Muslimin dalam bukunya yang berjudul perilaku antropologi sosial budaya dan kesehatan, bahwa masyarakat merupakan kesatuan hidup manusia yang berinteraksi sesuai dengan 
sistem adat istiadat yang berkesinambungan dan terikat oleh suatu rasa identitas. ${ }^{4}$

Masyarakat melaksanakan tradisi mabbaca-baca pabbilang penni ini hanya karena mengikuti orangorang kampung, karena jika tidak mengerjakan tradisi ini, maka orang tersebut akan dikucilkan oleh masyarakat.

Ketiga, Faktor Keyakinan. Faktor keyakinan merupakan salah satu faktor yang menyebabkan masyarakat tetap melaksanakan mabbaca-baca pabbilang penni. Masyarakat Kelurahan Kota Baru Reteh meyakini tradisi mabbaca-baca pabbilang penni harus dilaksanakan karena apabila hal ini tidak dilaksanakan oleh seseorang, maka mereka akan mendapatkan musibah. Musibah tersebut dapat berupa timbulnya penyakit maupun gangguan dalam mimpi.

\section{Nilai-Nilai Yang Terkandung Dalam Tradisi Mabbaca-Baca Pabbilang Penni}

Adapun nilai-nilai yang terkandung dalam Tradisi Mabbaca-Baca Pabbilang Penni, yaitu sebagai berikut:

Pertama, Nilai Religius (Agama). Dalam tradisi mabbaca-bacapabbilangpenni t terdapat sebuah nilai agama. Hal ini dapat dilihat bahwa nilai agama yang ada pada tradisi mabbaca-baca pabbilang penni, yaitu terdapatnya suatu unsur ibadah, yang di mana pada tradisi mabbaca-baca pabbilang penni ini terdapat suatu bentuk permohonan doa kepada Allah SWT yang dipimpin oleh seorang pabbaca untuk mendoakan keluarga/orang telah meninggal dan memohon doa keselamatan bagi keluarga yang ditinggalkan. Hal ini merupakan suatu bentuk ibadah kepada Allah dengan meyakini bahwa hanya kepadanya tempat untuk memohon pertolongan dan hal ini juga merupakan suatu bentuk rasa penghormatan warga masyarakat dalam menghargai keluarga tuan rumah yang sudah wafat.

Kedua, Nilai Sosial. Nilai sosial merupakan salah satu nilai yang terkandung dalam tradisi mabbaca-baca pabbilang penni, karena dapat kita ketahui bahwasanya dalam masyarakat akan terjadi sebuah interaksi antara satu masyarakat dengan masyarakat lainya. Dimensi manusia sebagai

4 Muslimin, Perilaku Antropologi Sosial Budaya dan Kesehatan. (Yogyakarta: CV Budi Utama, 2019), hlm.18. makhluk sosial berarti dalam hidupnya selalu bersama dan mengandung makna psikologis, yaitu di mana terdapatnya suatu dorongan untuk mencintai dan dicintai serta adanya kebahagiaan yang akan muncul terutama dari kepuasan rohani. Kesadaran akan interpedensi akan dapat membuat manusia saling membutuhkan dorongan dan motivasi untuk selalu bermanfaat terhadap sesamanya yang didasari oleh rasa solidaritas. Selain itu esensi manusia sebagai makhluk sosial merupakan suatu kesadaran manusia mengenai status dan posisi dirinya terhadap kehidupan bersama dalam suatu lingkungan dan bagaimana tanggung jawab serta melaksanakan kewajiban dalam kebersamaan tersebut. Adapun perwujudan manusia sebagai makhluk sosial terutama akan tampak pada kenyataan hidup bahwa tidak ada manusia yang mampu hidup tanpa bantuan orang lain. ${ }^{5}$

Manusia sebagai makhluk sosial yang tidak dapat hidup sendiri tanpa bantuan orang lain. Maka dari itu sebagai bentuk dari wujud kepedulian sosial kepada masyarakat, maka seseorang harus menampakkan pengabdian dirinya kepada masyarakat dengan keikutsertaan seseorang untuk berpartisipasi dalam aktivitas di masyarakat, seperti halnya keikutsertaan seseorang dalam pelaksanaan tradisi mabbaca-baca pabbilang penni. Nilai sosial dalam Tradisi mabbaca-baca pabbilang penni tampak pada perwujudan manusia sebagai makhluk sosial di mana hal ini dapat dibuktikan dengan adanya sikap yang disertai dengan tindakan untuk saling tolong menolong dalam proses persiapan pelaksanaan tradisi ini.

Selain itu, nilai sosial yang ada pada tradisi mabbaca-baca pabbilang penni ini dapat dilihat dalam masyarakat yang membentuk suatu wujud persatuan dan kesatuan dalam menjaga rasa solidaritas dalam masyarakat. Bukan hanya itu, dalam tradisi mabbaca-baca pabbilang penni terdapat nilai sosial yaitu berbagi, di mana hal ini tampak pada akhir dari pelaksanaan mabbaca-baca pabbilang penni para tetangga dan kerabat akan makan bersama serta tuan rumah biasanya akan membungkuskan makanan yang berlebih untuk

${ }^{5}$ Moh.Suhardi, Pengantar Pendidikan. (Jakarta Barat: PT. Indeks.2012), hlm. 15. 


\section{NUSANTARA; Journal for Southeast Asian Islamic Studies}

Vol. 16, No. 2, Desember 2020

para tetangga maupun kerabat dekat untuk dibawa pulang kerumah.

Ketiga, Nilai Moral. Pada dasarnya kata moral memiliki banyak arti berdasarkan sudut pandang yang berbeda-beda. Dalam kamus psikologi, disebutkan bahwa moral mengacu pada akhlak yang sesuai dengan peraturan sosial, atau menyangkut hukum atau adat kebiasaan yang mengatur tingkah laku. Sedangkan dalam psikologi perkembangan, bahwa perilaku moral merupakan yang sesuai dengan kode moral kelompok sosial. Adapun arti dari moral itu sendiri adalah tata cara, kebiasaan dan adat. Perilaku moral dikendalikan oleh konsep-konsep moral atau peraturan perilaku yang telah menjadi kebiasaan bagi anggota suatu budaya. Sementara dalam webster's new world dictionary bahwasanya moral merupakan sesuatu yang berkaitan atau berhubungan dengan kemampuan untuk menentukan benar salah dan baik buruknya tingkah laku.

Jadi dari tiga definisi diatas dapat dilihat bahwa moral merupakan suatu keyakinan mengenai benar salah, baik dan buruk tingkah laku seseorang dalam bermasyarakat yang diatur berdasarkan kesepakatan sosial. Adapun nilai moral yang terdapat dalam tradisi mabbaca-baca pabbilang penni dapat dilihat pada sikap keberanian untuk mempertahankan tradisi mabbaca-baca pabbilang penni sebagai suatu yang diyakini dan suatu kewajiban untuk selalu bertanggung jawab dalam melaksanakan tradisi ini meskipun berada di tanah rantauan dengan tetap menjunjung sikap toleransi antar warga masyarakat yang ada di Kelurahan Kota Baru Reteh.

\section{Kesimpulan}

Berdasarkan hasil penelitian mengenai Tradisi Mabbaca-baca pabbilang penni di Kelurahan Kota Baru Reteh, maka penelitian ini dapat disimpulkan sebagai berikut:

Pertama, Mabbaca-baca pabbilang penni atau membaca doa perhitungan hari arwah merupakan suatu usaha yang dilakukan oleh masyarakat suku Bugis di Kelurahan Kota Baru Reteh sebagai bentuk pembacaan doa atau permohonan doa kepada Allah SWT yang dipimpin oleh seorang pabbaca untuk mendoakan keluarga/orang telah meninggal dan memohon doa keselamatan bagi keluarga yang ditinggalkan. Media yang digunakan pada tradisi mabbaca-baca pabbilang penni, yaitu: dupa atau kemenyan. Terdapat beberapa lauk pauk serta kue yang biasa disajikan pada tradisi mabbaca-baca pabbilang penni.

Kedua, Makna simbolik dalam tradisi mabbacabaca pabbilang penni pada masyarakat suku Bugis, yaitu setiap simbol yang digunakan dalam proses tradisi mabbaca-baca pabbilang penni memiliki makna tersendiri, yang di mana pemaknaan simbol tersebut didasarkan pada karakteristik dari simbol itu sendiri baik dari rasa maupun bentuknya. Namun, terdapat suatu simbol yang sudah tidak diketahui lagi oleh masyarakat setempat.

Ketiga, Faktor yang Menyebabkan Masyarakat Suku Bugis di Kelurahan Kota Baru Reteh Kecamatan Keritang Kabupaten Indragiri Hilir Melaksanakan Tradisi Mabbaca-Baca Pabbilang Penni, yaitu: faktor adat yang di mana dalam hal ini masyarakat melaksanakan tradisi ini dikarenakan mengikuti dan meneruskan ajaran nenek moyang, faktor sosial dalam hal ini masyarakat melaksanakan tradisi ini sebagai bentuk untuk mengikuti persatuan dan menghindari sikap pengucilan dari masyarakat setempat dan pada faktor keyakinan dapat dilihat bahwa masyarakat melaksanakan tradisi ini didasarkan pada perspektif dari masyarakat setempat dan pengalaman.

Adapun nilai-nilai yang terkandung dalam tradisi mabbaca-baca pabbilang penni yaitu pertama nilai religius (agama), di mana hal ini dapat dilihat pada permohonan doa kepada Allah. Kedua nilai sosial, di mana hal ini dapat dilihat pada bentuk interaksi antar masyarakat yang saling memperlihatkan sikap kepedulian antar masyarakat. Ketiga nilai moral, dalam hal ini masyarakat diajarkan mengenai baik dan buruk tingkah laku manusia. 
Nur Kamalia Tradisi Mabbaca-baca Pabbilang Penni...

\section{DAFTAR PUSTAKA}

Rafael Raga Maran, Manusia dan Kebudayaan Dalam Perspektif Ilmu Budaya Dasar, Cet. I. Jakarta: PT. Rineka Cipta,2000.

Ayat al-Qur'an Dengan Terjemahan Dalam Skripsi ini di Kutip Dari Al-Qur'an Word Versi 2010

Albi Anggito Dan Johan Setiawan, Metode Penelitian Kualitatif. Jawa Barat: CV.Jejak, 2018.

1Sugiyono, Metode Penelitian Kuantitatif. Bandung:ALFABETA,Cv. 2019.

Burhan Bungin, Metodologi Penelitian Sosial Dan Ekonomi: Format-Format Kuantitatif Dan Kualitatif Untuk Studi Sosiologi, Kebijakan, Komunikasi, Manajemen, dan Pemasaran Cet.1. Jakarta:Kencana Prenada Media Grup. 2013.

Bachtiar S. Bachri, "Meyakinkan Validitas Data Melalui Trianggulasi Pada Penelitian Kualitatif', Jurnal Teknologi Pendidikan, Vol.10 No.1, April 2010

Muslimin, Perilaku Antropologi Sosial Budaya dan Kesehatan. Yogyakarta: CV Budi Utama, 2019.

Moh.Suhardi, Pengantar Pendidikan. Jakarta Barat: PT. Indeks. 2012.

Dian Ibung, Mengembangkan Nilai Moral Pada Anak. Jakarta: PT. Elex Media Komputindo, 2009. 